\title{
FORMULATION DEVELOPMENT AND STATISTICAL OPTIMIZATION OF A BILAYER TABLET OF BOSENTAN MONOHYDRATE AND SILDENAFIL CITRATE IN MANAGEMENT OF PULMONARY ARTERIAL HYPERTENSION
}

\author{
PEARL PIRES DIGHE ${ }^{1,2 *}$, H. M. TANK ${ }^{3}$ \\ 1Department of Pharmaceutics, PES's Rajaram and Tarabai Bandekar College of Pharmacy, Ponda, Goa, ${ }^{2}$ Faculty of Doctoral Studies and \\ Research, School of Pharmacy, RK University, Rajkot, Gujarat, India, ${ }^{3}$ Department of Pharmaceutics, Atmiya Institute of Pharmacy, Rajkot, \\ Gujarat, India \\ Email: pirespearl@gmail.com
}

Received: 21 Nov 2018, Revised and Accepted: 12 Jan 2019

\begin{abstract}
Objective: The current study aims at fabrication of an oral bilayer matrix tablet of bosentan monohydrate and sildenafil citrate; the optimisation of their in vitro release and characterization, thereby reducing the side effects associated with bosentan, reducing dosing frequency and increasing patient compliance in the management of pulmonary arterial hypertension.

Methods: Methocel K4M Premium DC2, a directly compressible HPMC grade was used as the sustained release polymer. Pregelatinised starch is used as a diluent and release modifier and sodium lauryl sulphate (SLS) as a solubiliser. The blends of both layers were prepared, evaluated for precompression characteristics and compressed by direct compression. The compressed bilayer tablets were evaluated for their hardness, weight variation, friability, content uniformity and swelling index. The principle objective was to assess the influence of the above variables on in vitro drug release of Bosentan using a $2^{3}$ factorial design. Responses are measured as drug release at 2h (Q2), 6h (Q6) and 10h (Q10).
\end{abstract}

Results: HPMC and pregelatinized starch form a synergistic gel thereby controlling drug release of bosentan for a 12 hour period. Batch BS09 consisting of $40 \mathrm{mg}$ HPMC, $30 \mathrm{mg}$ Pregeletinized starch and $5 \mathrm{mg}$ SLS showed adequate controlled release for a $12 \mathrm{~h}$ period. Immediate release layer of sildenafil citrate showed optimum drug release of $102.96 \%$ within $30 \mathrm{~min}$.

Conclusion: Bilayer tablet of bosentan and sildenafil is an ideal combination for patients failing monotherapy in pulmonary arterial hypertension.

Keywords: Bilayer tablet, Bosentan monohydrate, Sildenafil citrate, HPMCK4M DC2Premium, Preletinized starch, SLS, Design expert

(C) 2019 The Authors. Published by Innovare Academic Sciences Pvt Ltd. This is an open-access article under the CC BY license (http://creativecommons.org/licenses/by/4.0/) DOI: http://dx.doi.org/10.22159/ijap.2019v11i2.30927

\section{INTRODUCTION}

Pulmonary arterial hypertension (PAH) is a rare disease in which remodelling of the pulmonary vasculature progressively leads to increased pulmonary vascular resistance, right ventricular failure. $\mathrm{PAH}$ is a specific type of pulmonary hypertension that is caused by the development of scar tissue in the tiny blood vessels of the lung. This scar tissue blocks the blood flow through the lungs and causes the pressure in those blood vessels to increase [1].

The dual endothelin receptor antagonist, bosentan, is an orally active therapy, which is effective in the treatment of pulmonary arterial hypertension the most significant adverse event in patients on bosentan treatment is the potential development of abnormal hepatic function and specifically a rise in hepatic amino transaminases [2]. It has an oral bioavailability of $50 \%$ and plasma elimination half-life of $5 \mathrm{~h}$ [3]. Administration of bosentan as a controlled release formulation due to the short half-life would be desirable in maintaining the plasma therapeutic levels and thereby reducing adverse effects.

Sildenafil is an orally active, potent and selective inhibitor of phosphodiesterase type 5 (PDE5) present throughout the body and is found in high concentrations in the lungs [4]. Inhibition of PDE5 enhances the vasodilator effects of nitric oxide in pulmonary hypertension by preventing the degradation of cyclic guanosine monophosphate (cGMP), which promotes relaxation of vascular smooth muscle and increases blood flow. Sildenafil has been found to produce a relatively selective reduction in pulmonary artery pressure without adverse systemic hemodynamic effects [5].

Pulmonary arterial hypertension is a disease with complex pathogenesis, for which combination therapy is an attractive option. Studies have assessed the impact of sequential combination therapy of bosentan and sildenafil on both short-term responses and longterm outcomes in patients failing on monotherapy [6].
The multi-layered tablet concept has been utilized to develop sustained release formulations and co-administers two drugs as a fixed dose combination [7]. The present study aims to combine the two drugs bosentan and sildenafil for the treatment of pulmonary arterial hypertension as a bilayer tablet. The combination therapy would help to lower pulmonary hypertension by different mechanisms of action in patients failing monotherapy, thereby reducing frequency of dose, side effects and thus improving patient compliance. The objective was to formulate a bilayer tablet wherein bosentan is sustained release and sildenafil is the immediate release layer. Methocel K4M Premium DC2, a directly compressible hydroxypropyl methylcellulose (HPMC) grade has been used as the sustained release polymer. Pregelatinized starch is used as a diluent and release modifier and sodium lauryl sulphate (SLS) as a solubiliser. The further objective was to assess the influence of the above variables on drug release of bosentan. This was accomplished using the statistical design of experiments using the Design expert software, trial version 11 .

\section{MATERIALS AND METHODS}

Bosentan monohydrate was gifted by Cipla Ltd. Goa, sildenafil citrate was gifted by Unichem Laboratories Pvt. Ltd. Methocel K4M Premium DC was gifted by Colorcon Asia Pvt. Ltd. Goa; pregelatinized starch byIndocco Remeides Pvt. Ltd. Goa; MCC pH 102 and other excipients from Arihant chemicals, Mumbai.

\section{Formulation of sildenafil citrate immediate release blend}

The dose of sildenafil which is the immediate release layer is $20 \mathrm{mg}$. $22.47 \mathrm{mg}$ of sildenafil citrate equivalent to sildenafil is weighed. The blend for immediate release layer as given in table 1 was prepared by mixing the drug with super disintegrant in the mortar and pestle, following which other ingredients were blended into, mixed for 15 min and sieved through sieve no\# 80 . The tablets of sildenafil were compressed using Rimek Mini Press II MT (Karnavati Engineering Private Ltd.). Final weight of the tablet was $130 \mathrm{mg}$ [8]. 
Table 1: Formulation of sildenafil citrate blends

\begin{tabular}{|c|c|c|c|c|}
\hline \multirow[t]{2}{*}{ Ingredients (mg/tab) } & \multicolumn{4}{|c|}{ Formulations } \\
\hline & SC01 & SC02 & SC03 & SC04 \\
\hline Sildenafil citrate & 22.47 & 22.47 & 22.47 & 22.47 \\
\hline Crosscarmellose sodium & 5 & 10 & --- & --- \\
\hline Crosspovidone & --- & ---- & 5 & 10 \\
\hline Calcium Hydrogen Phosphate anhydrous & 40 & 40 & 40 & 40 \\
\hline MCC Ph102 & 61 & 61 & 61 & 61 \\
\hline Magnesium stearate & 1 & 1 & 1 & 1 \\
\hline Aerosil & 0.53 & 0.53 & 0.53 & 0.53 \\
\hline Total tablet weight (mg) & 130 & 135 & 130 & 135 \\
\hline
\end{tabular}

MCC: Microcrystalline Cellulose

\section{Formulation of bosentan monohydrate sustained release component using $2^{3}$ factorial design}

Various preformulation trials were carried out for selection of matrix polymer to sustain the release of bosentan. Methocel K4M PemiumDC2 was found to show promising sustained release effect for desired period of time. The sustained release layer was formulated with the drug, Methocel K4M PemiumDC2, pregelatinized starch as a diluent and release modifier and sodium lauryl sulfate (SLS) as a solubilizer. The effect of each key ingredient was studied using a $2^{3}$ factorial design containing 3 factors at 2 levels and center point batches repeated four times to assess the experimental error of the model. The dependent response variables measured were the percentage of bosentan release at 2 , 6 and $10 \mathrm{~h}$. Table 2 shows the variables and their concentrations according to the design expert software trial version 11.

Table 2: Experimental design for bosentan monohydrate component as per design expert

\begin{tabular}{llll}
\hline $\begin{array}{l}\text { Coded } \\
\text { values }\end{array}$ & Actual value & \\
\cline { 2 - 3 } & $\mathbf{X}_{1}$ & $\mathbf{X}_{2}$ \\
\cline { 2 - 3 } & $\begin{array}{l}\text { Concentration of methocel K4M premium DC2 } \\
\text { per tablet }(\mathbf{m g})\end{array}$ & $\begin{array}{l}\text { Concentration of pregelatinized starch } \\
\text { per tablet (mg) }\end{array}$ & \multicolumn{1}{c}{$\begin{array}{l}\text { Concentration of SLS per } \\
\text { tablet (mg) }\end{array}$} \\
\hline-1 & 30 & 20 \\
+1 & 50 & 40 & 0 \\
\hline
\end{tabular}

A total of twelve batches were compressed (table 3), of which eight batches-BS01-BS08, comprised of a varying concentration of independent variables and BS09-BS12 were the four repeated center point batches. The blend of sustained release was prepared by mixing drug with Methocel K4M premium DC2 and SLS in a laboratory blender for $15 \mathrm{~min}$. The rest of the ingredients were blended into for the next $10 \mathrm{~min}$. Finally, magnesium stearate was added and blended. The tablets were compressed using Rimek Mini Press II MT of Karnavati Engineering Private Ltd. The final weight of the sustained release component was $170 \mathrm{mg}$.

Both the immediate and sustained release blends were evaluated for precompression parameters such as bulk density, tapped density, angle of repose and carr's compressibility index $[9,10]$.

Table 3: Formulation blends of bosentan monohydrate layer

\begin{tabular}{|c|c|c|c|c|c|c|c|c|c|c|c|c|}
\hline Composition & BS01 & BS02 & BS03 & BS04 & BS05 & BS06 & BS07 & BS08 & BS09 & BS010 & BS11 & BS12 \\
\hline Bosentan monohydrate & 64.54 & 64.54 & 64.54 & 64.54 & 64.54 & 64.54 & 64.54 & 64.54 & 64.54 & 64.54 & 64.54 & 64.54 \\
\hline HPMC K4M DC & 30 & 50 & 30 & 50 & 30 & 50 & 30 & 50 & 40 & 40 & 40 & 40 \\
\hline Pregelatinized starch & 20 & 20 & 40 & 40 & 20 & 20 & 40 & 40 & 30 & 30 & 30 & 30 \\
\hline SLS & 0 & 0 & 0 & 0 & 10 & 10 & 10 & 10 & 5 & 5 & 5 & 5 \\
\hline sunset yellow FCF & 0.46 & 0.46 & 0.46 & 0.46 & 0.46 & 0.46 & 0.46 & 0.46 & 0.46 & 0.46 & 0.46 & 0.46 \\
\hline magnesium stearate & 2 & 2 & 2 & 2 & 2 & 2 & 2 & 2 & 2 & 2 & 2 & 2 \\
\hline MCC ph102 (qs) & 53 & 33 & 33 & 13 & 43 & 23 & 23 & 3 & 28 & 28 & 28 & 28 \\
\hline Total weight (mg) & 170 & 170 & 170 & 170 & 170 & 170 & 170 & 170 & 170 & 170 & 170 & 170 \\
\hline
\end{tabular}

Formulation of bilayered tablet of bosentan monohydrate and sildenafil citrate

The twelve blends of bosentan monohydrate were compressed with the optimised sildenafil blend SC01 using tablet compression machine (Rimek Mini Press II MT (Karnavati Engineering Private Ltd) and were further evaluated. The bilayer tablet was prepared by adding the sustained release blend of bosentan into the die cavity and compressing lightly followed by compressing the immediate release blend of sildenafil over it thereby obtaining the bilayer tablet [11].

\section{Evaluation}

The bilayered tablet was evaluated for physical tests like hardness (Monsanto hardness tester-Pathak Electrical Works), friability (Roche friabilator-Pathak Electricals), thickness (Vernier calliper-Bliss Classic), drug content, uniformity of weight and swelling index.
Incompatibilities between drugs and excipients were ruled out by DSC and FTIR studies. In vitro disintegration time for sildenafil immediate release component was evaluated using USP tablet disintegration apparatus with $0.1 \mathrm{~N} \mathrm{Hcl}$ as medium. The volume of medium used was $900 \mathrm{ml}$ and the temperature was $37 \pm 0.5{ }^{\circ} \mathrm{C}$. The time taken for complete disintegration of the IR layer was measured [9-11].

\section{In vitro drug release}

The in vitro drug release of bilayered tablet was studied using $900 \mathrm{ml} 0.1 \mathrm{~N} \mathrm{HCl}$ for the first one hour followed by $11 \mathrm{~h}$ in 900 $\mathrm{ml}$ phosphate buffer $\mathrm{pH} 7.2$ using USP type II paddle apparatus using at $50 \mathrm{rpm}$ at $37 \pm 0.5{ }^{\circ} \mathrm{C}$. The samples were withdrawn every one hour for a period of $12 \mathrm{~h}$ and replaced with the fresh buffer. The samples were analysed using double beam UV-Visible spectrophotometer at $271 \mathrm{~nm}$ and $290 \mathrm{~nm}$ for bosentan and sildenafil respectively [12]. 


\section{Swelling studies}

The tablets were weighed (W0) and placed in a petridish containing buffer and incubated at $37 \pm 1^{\circ} \mathrm{C}$. At regular time intervals until $12 \mathrm{~h}$, the tablet was removed carefully and the excess buffer was removed with blotting paper. The swollen tablet was then reweighed $(\mathrm{Wt})$ and the percent swelling was calculated as follows:

$$
\% \text { swelling }=\{(\mathrm{Wt}-\mathrm{W} 0) / \mathrm{W} 0\} \times 100
$$

Where $\mathrm{Wt}$ is the weight of tablet at time $t$ and $\mathrm{W} 0$ is the initial weight of tablet. The swelling index was calculated [13].

\section{Statistical analysis}

Statistical analysis was done using Design Expert ${ }^{\circledR} 11$ software. The responses analysed were the drug release Q2 (at $2 \mathrm{~h}$ ), Q6 (at $6 \mathrm{~h})$ and Q10 $(10 \mathrm{~h})$. The effect of independent variables on response was represented through contour plots and response surface plots. Significance of results was studied through twoway analysis of variance (ANOVA) wherein $\mathrm{P}<0.05$ was considered significant [13-14].

\section{Drug release kinetics}

Kinetics of drug release was studied by analysing the dissolution data through zero order, first order, Higuchi's and Korsmeyer Peppas equations [15].

\section{Accelerated stability study}

The optimized batch was subjected to stability study as per ICH guidelines [16]

\section{RESULTS AND DISCUSSION}

The results of precompression characteristic have been tabulated in table 4 and 5 for immediate release and sustained release blend respectively. Bulk and tapped densities indicate good packing properties. The carr's index for all formulations was below $17.3 \%$ indicating good flow and compressibility. The angle of repose for all blends lies between the ranges of $12.64^{\circ}-22.75^{\circ}$ further ascertaining good flow.

The compressed tablets were evaluated for their hardness, weight variation, friability, content uniformity, and diameter. As shown in table 6 , all the parameters were found to be within range.

Table 4: Precompression characteristics of sildenafil citrate blends

\begin{tabular}{lllll}
\hline Formulation code & Angle of repose $^{\mathrm{a}^{\mathrm{o}}}$ & ${\text { Bulk density }(\mathrm{g} / \mathbf{m l})^{\mathrm{a}}}^{\mathrm{a}}$ & Tapped density $\mathbf{~} \mathbf{( g} / \mathbf{m l})^{\text {Carrs Index }^{\mathrm{a}}(\%)}$ \\
\hline SC01 & $21.84 \pm 0.57$ & $0.43 \pm 0.03$ & $0.51 \pm 0.03$ & 15.68 \\
SC02 & $21.37 \pm 0.19$ & $0.43 \pm 0.04$ & $0.52 \pm 0.08$ & 17.30 \\
SC03 & $22.49 \pm 0.42$ & $0.42 \pm 0.05$ & $0.50 \pm 0.07$ & 16 \\
SC04 & $22.75 \pm 0.38$ & $0.40 \pm 0.03$ & $0.48 \pm 0.05$ & 16.66 \\
\hline
\end{tabular}

amean $\pm \mathrm{SD}, \mathrm{n}=3$

Table 5: Precompression characteristics of bosentan monohydrate blends

\begin{tabular}{lllll}
\hline Formulation code & Angle of repose $^{\mathrm{a}}$ & Bulk density $^{\mathrm{a}}(\mathrm{g} / \mathbf{m l})$ & Tapped density $^{\mathrm{a}} \mathbf{( g / m l )}$ & Carrs $^{\text {index }} \mathbf{( \% )}$ \\
\hline BS01 & $21.57 \pm 0.62$ & $0.41 \pm 0.08$ & $0.46 \pm 0.04$ & 10.86 \\
BS02 & $20.14 \pm 0.22$ & $0.42 \pm 0.05$ & $0.48 \pm 0.11$ & 12.5 \\
BS03 & $18.54 \pm 0.87$ & $0.43 \pm 0.07$ & $0.49 \pm 0.09$ & 12.22 \\
BS04 & $19.31 \pm 1.0$ & $0.38 \pm 0.1$ & $0.42 \pm 0.08$ & 9.52 \\
BS05 & $18.54 \pm 0.32$ & $0.36 \pm 0.08$ & $0.41 \pm 0.06$ & 12.19 \\
BS06 & $16.66 \pm 0.54$ & $0.35 \pm 0.04$ & $0.42 \pm 0.05$ & 16.66 \\
BS07 & $15.41 \pm 0.87$ & $0.36 \pm 0.09$ & $0.40 \pm 0.08$ & 10.0 \\
BS08 & $12.64 \pm 0.55$ & $0.34 \pm 0.08$ & $0.39 \pm 0.09$ & 12.8 \\
BS09-BS12 & $14.65 \pm 0.21$ & $0.33 \pm 0.04$ & $0.38 \pm 0.24$ & 13.15 \\
\hline
\end{tabular}

amean $\pm S D, n=3$

Table 6: Post compression characteristics of bilayered tablet

\begin{tabular}{|c|c|c|c|c|c|c|c|}
\hline $\begin{array}{l}\text { Formulation } \\
\text { code }\end{array}$ & $\begin{array}{l}\text { Hardness } \\
\left(\mathrm{Kg} / \mathrm{cm}^{2}\right)^{\mathrm{a}}\end{array}$ & $\begin{array}{l}\text { Thickness } \\
(\mathrm{mm})\end{array}$ & $\begin{array}{l}\text { Weight Variation } \\
\text { (mg) }\end{array}$ & $\begin{array}{l}\text { Friability }{ }^{a} \\
(\%)\end{array}$ & $\begin{array}{l}\text { DT for IR } \\
\text { layer (s) }\end{array}$ & $\begin{array}{l}\text { Drug content } \\
\text { (SR layer) }(\%)\end{array}$ & $\begin{array}{l}\text { Drug content } \\
\text { (IR layer) }(\%) \\
\end{array}$ \\
\hline BS01 & $8.5 \pm 0.23$ & 4 & $300 \pm 0.56$ & $0.29 \pm 0.0021$ & 79 & $99.12 \pm 0.67$ & $99.21 \pm 0.57$ \\
\hline BS02 & $10.3 \pm 0.35$ & 4 & $300 \pm 0.34$ & $0.41 \pm 0.0074$ & 85 & $99.87 \pm 1.07$ & $99.57 \pm 0.64$ \\
\hline BS03 & $9.8 \pm 0.87$ & 4 & $300 \pm 0.57$ & $0.51 \pm 0.0041$ & 84 & $100.35 \pm 0.44$ & $98.64 \pm 1.28$ \\
\hline BS04 & $10.5 \pm 0.47$ & 4 & $300 \pm 0.69$ & $0.38 \pm 0.005$ & 90 & $99.74 \pm 0.56$ & $99.24 \pm 0.55$ \\
\hline BS05 & $8.7 .0 \pm 0.17$ & 4 & $300 \pm 0.46$ & $0.63 \pm 0.0087$ & 75 & $100.67 \pm 0.32$ & $98.54 \pm 0.97$ \\
\hline BS06 & $10.1 \pm 0.61$ & 4 & $300 \pm 0.49$ & $0.49 \pm 0.0097$ & 89 & $98.62 \pm 1.06$ & $99.69 \pm 1.64$ \\
\hline BS07 & $9.5 \pm 0.31$ & 4 & $300 \pm 0.78$ & $0.55 \pm 0.0035$ & 88 & $99.79 \pm 1.13$ & $98.82 \pm 1.47$ \\
\hline BS08 & $11.0 \pm 0.45$ & 4 & $300 \pm 0.81$ & $0.17 \pm 0.0047$ & 100 & $100.54 \pm 0.64$ & $99.16 \pm 0.57$ \\
\hline BS09-BS12 & $10.3 \pm 0.36$ & 4 & $300 \pm 0.74$ & $0.26 \pm 0.0046$ & 89 & $99.34 \pm 0.61$ & $98.54 \pm 1.22$ \\
\hline
\end{tabular}

amean $\pm S D, n=3$

\section{Drug-excipient compatibility}

\section{DSC studies}

The thermograph of pure drug bosentan monohydrate showed the melting point to be $197.94{ }^{\circ} \mathrm{C}$ and of sildenafil citrate 187.30
${ }^{\circ} \mathrm{C}$, which is as reported in the literature. The thermographs of the mixture of both drugs, as well as drug and excipient mixtures, does not reveal a significant change in the melting points of bosentan and sildenafil, thus ruling out incompatibilities as depicted in fig. 1. 


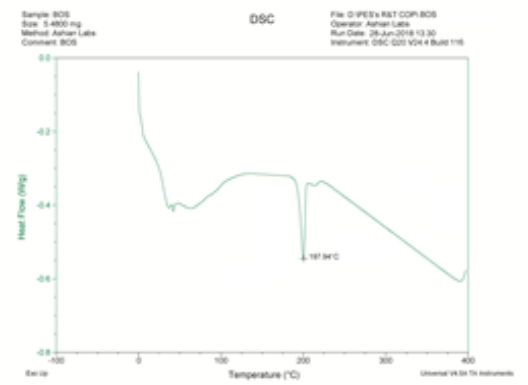

DSC of pure drug Bosentan Monohydrate

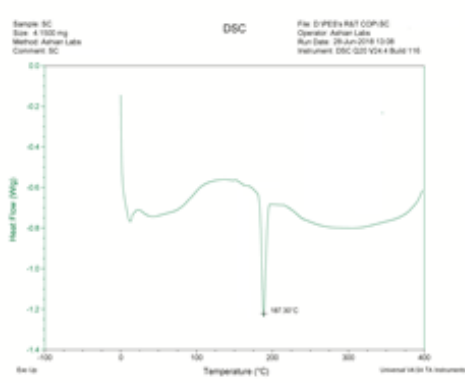

DSC of pure drug Sildenafil Citrate

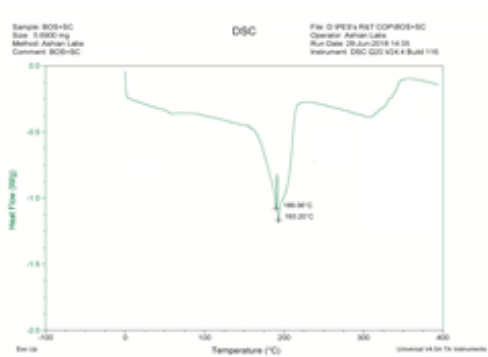

DSC of mixture of Bosentan and sildenafil citrate

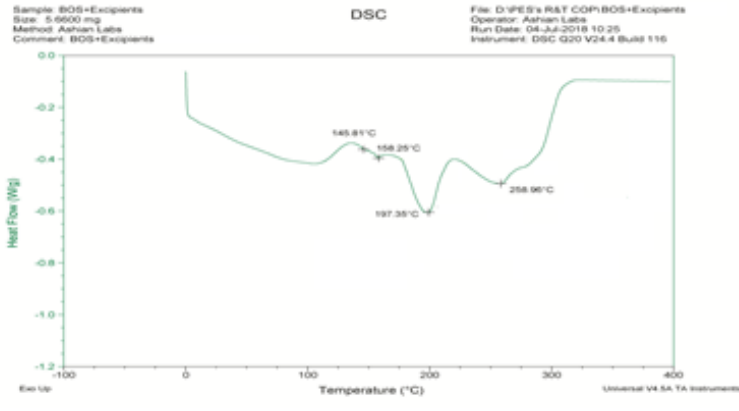

DSC of mixture of Bosentan Monohydrate with excipients

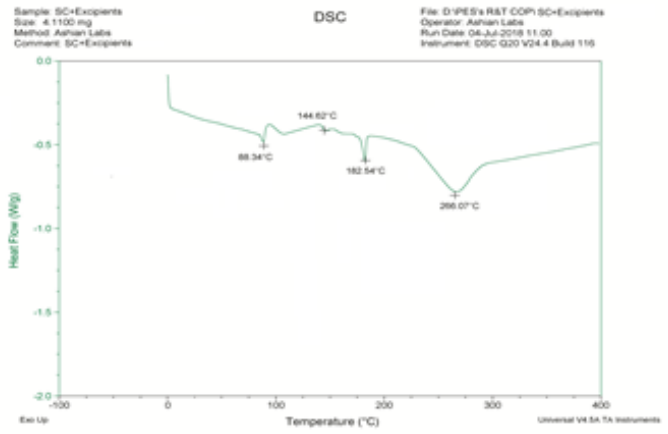

DSC of mixture of Sildenafil Citrate with excipients

Fig. 1: Compatibility studies of drugs and excipients using DSC

\section{In vitro drug release}

From the four batches of sildenafil citrate, SC01 containing croscarmellose sodium as disintegrant showed optimum drug release of $102.96 \%$ within 30 min. Hence this blend was further selected to be compressed against the 12 batches of bosentan monohydrate sustained release blends.

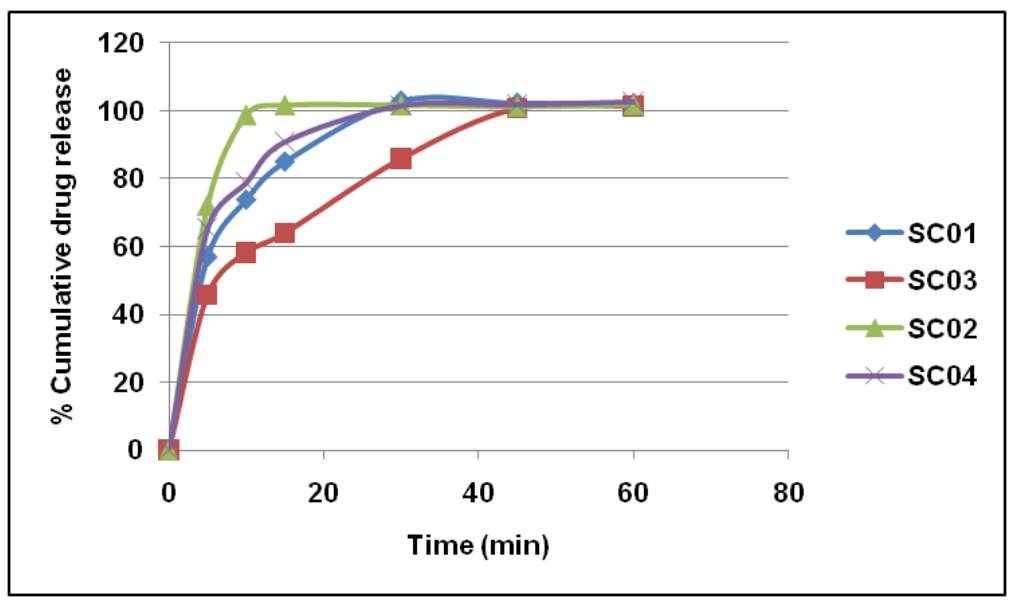

Fig. 2: Cumulative drug release profiles of sildenafil citrate immediate release component $(m e a n \pm S D, n=3)$

The release of sustained release bosentan monohydrate from the 12 batches of bilayer tablets is as given in fig. 3. All batches showed drug release varying from 8-12 $\mathrm{h}$ depending on the concentration of independent variables. Batches BS01-BS04 that do not contain solubiliser SLS do not show complete drug release at the end of $12 \mathrm{~h}$. This may be attributed to the saturation of the drug released in the dissolution vessel after 5-6 h. Formulations BS05-BS09 containing SLS as solubilizer showed adequate drug release. Formulations BS05 and BS07 containing $30 \mathrm{mg}$ of HPMC
K4M DC2 Premium per tablet could control the release for 8-9 h, whereas formulations BS06 and BS08 containing $50 \mathrm{mg}$ HPMC showed adequate control for a $12 \mathrm{~h}$ period as desired. Pregelatinized starch was observed to have a synergistic effect along with HPMC on controlling the drug release. Formulations BS09 which was the center point batch containing $40 \mathrm{mg} \mathrm{HPMC}, 30$ mg pregelatinized starch and $5 \mathrm{mg}$ SLS per tablet was observed to be the best-optimised formulation. The dissolution profile of the optimised bilayer tablet is depicted in fig. 4 . 


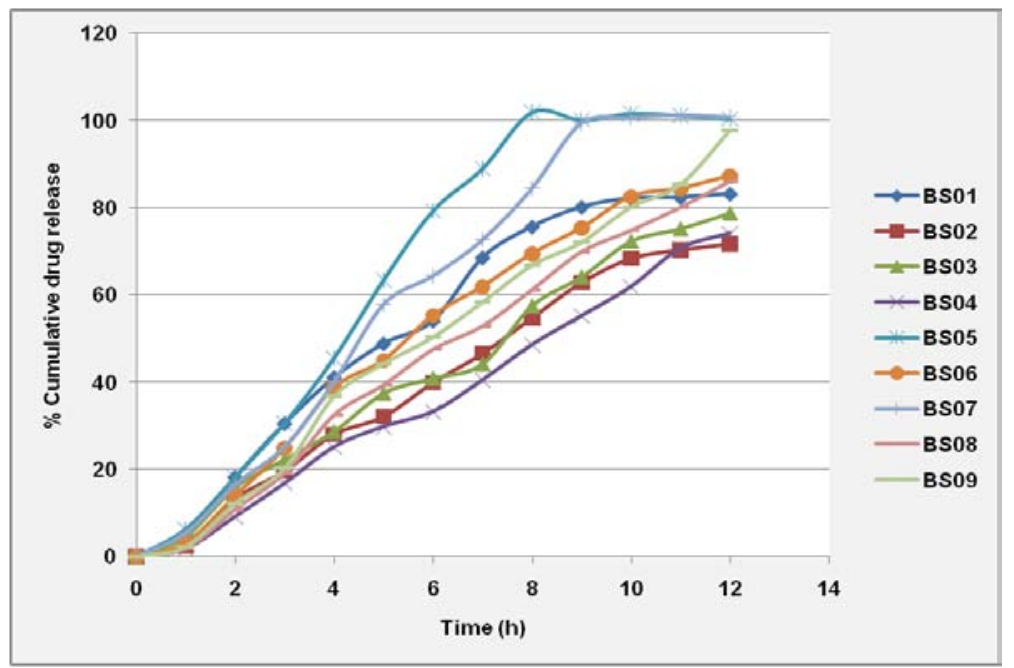

Fig. 3: Cumulative drug release profiles of bosentan monohydrate sustained release component $(m e a n \pm S D, n=3)$

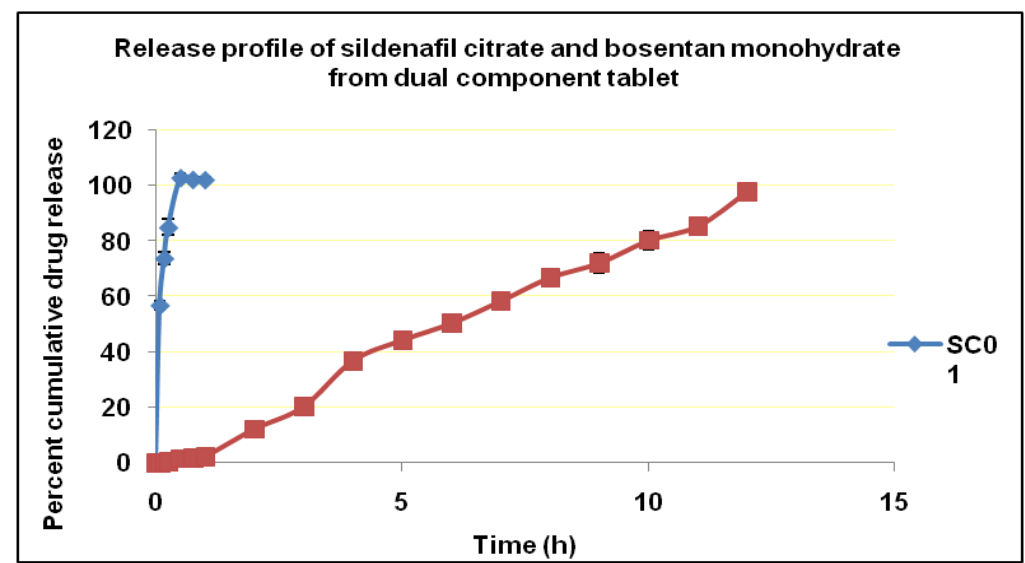

Fig. 4: Dissolution profile of optimised batch of bilayer tablet (mean $\pm S D, n=3$ )

To describe the entire dissolution profile, three-time points were considered in the design expert software. Fig. 5 shows the response surface plot for drug release at $2 \mathrm{~h}(\mathrm{Q} 2)$. As depicted, as the concentration of HPMC increases from $30 \mathrm{mg}$ to $50 \mathrm{mg}$ per tablet, the percent drug released is controlled. The same phenomenon is observed with pregelatinized starch as well, but to a lesser extent than HPMC. SLS does not have a significant effect at $2 \mathrm{~h}$.
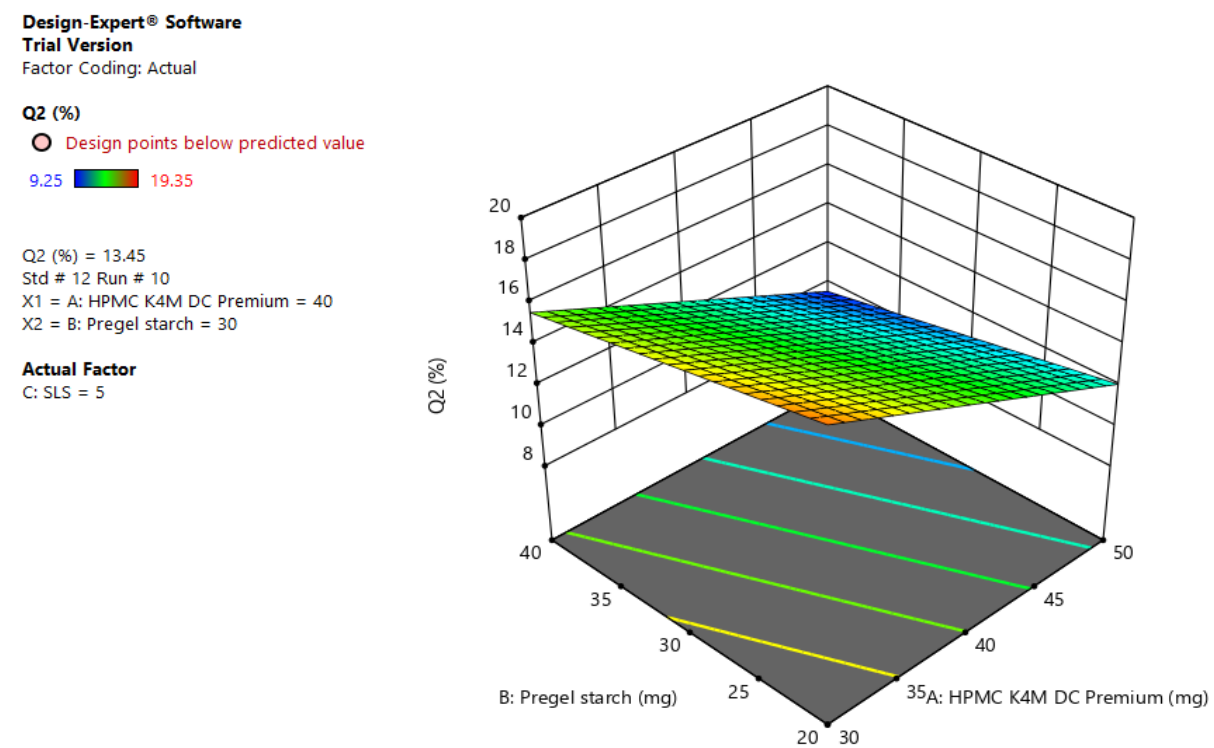

Fig. 5: Response surface plot for drug release at $2 \mathrm{~h}(\mathrm{Q} 2)(\mathrm{n}=3)$ 
At $6 \mathrm{~h}$ and $10 \mathrm{~h}$, HPMC continues to show a dominant effect on controlling the drug release along with pregelatinized starch. This is attributed to the formation of swollen gel of HPMC. HPMC along with pregelatinized starch forms a synergistic matrix gel thereby influentially controlling the drug release for $12 \mathrm{~h}$ period. The influence of pregelatinized starch is most dominant at $6 \mathrm{~h}$. A very significant influence of SLS was observed at $6 \mathrm{~h}$ and $10 \mathrm{~h}$. As depicted in fig. 6 and
7 it was observed that as SLS concentration increases from 0 to $10 \mathrm{mg}$ per tablet the release of drug increases at $6 \mathrm{~h}$ and $10 \mathrm{~h}$. This may be attributed to the fact that bosentan being a BCS class II drug, having a solubility of around $40 \mathrm{mg} / 100 \mathrm{ml}$ in phosphate buffer $\mathrm{pH} 7.2$, may pose a problem in the drug getting solubilised in the dissolution vessel after $6 \mathrm{~h}$. Therefore the addition of SLS as a solubiliser in the tablet helps to enhance the solubility of the drug as it is released.

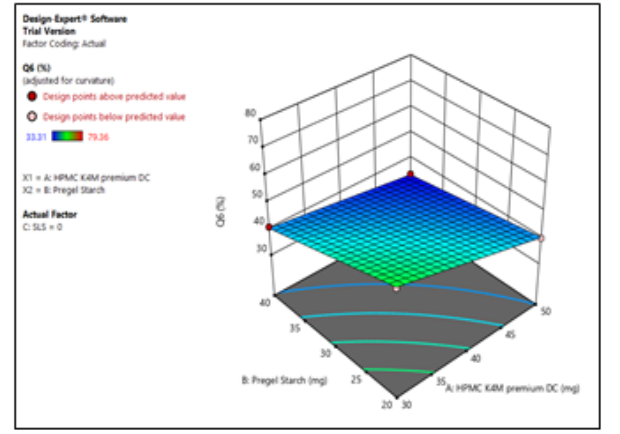

(a)

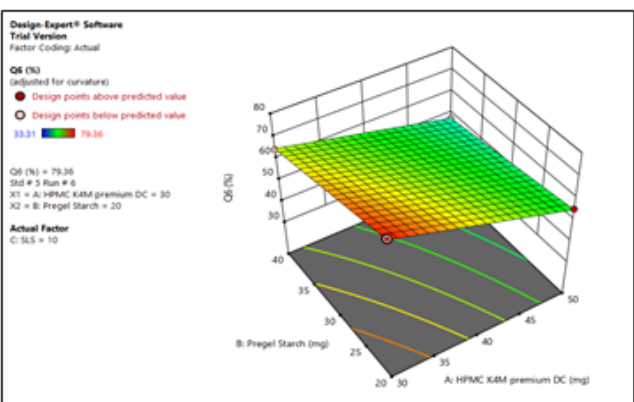

(c)

Fig. 6: Response surface plot for drug release at $6 \mathrm{~h}(\mathrm{Q} 6)(\mathrm{n}=3)$, fig. 6(a) Drug release at $6 \mathrm{~h}$ when concentration of SLS is 0 , fig. 6(b) Drug

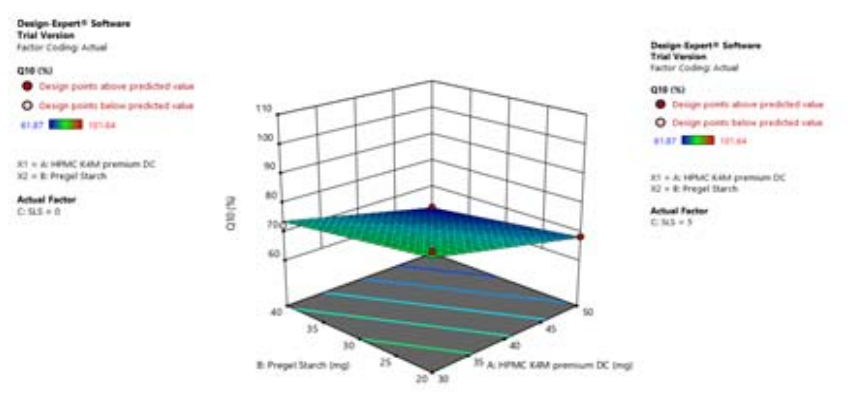

(a)

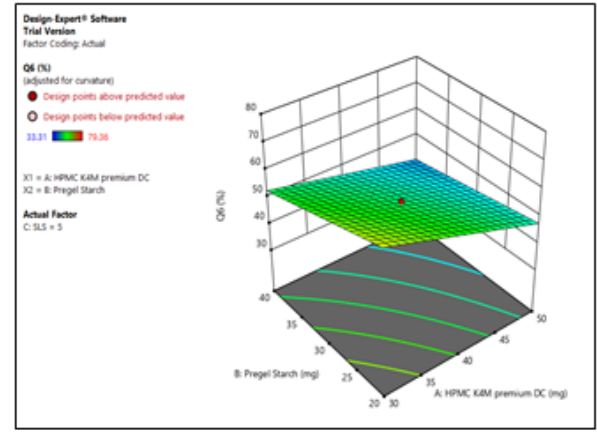

(b)

\section{release at $6 \mathrm{~h}$ when concentration of SLS is 5, fig. 6(c) Drug release at $6 \mathrm{~h}$ when concentration of SLS is 10}

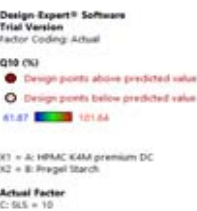

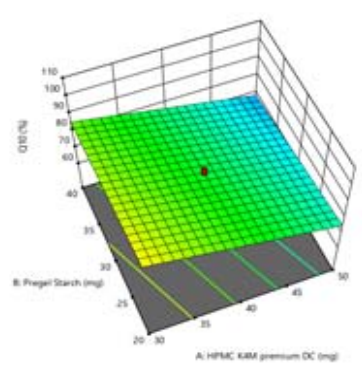

(b)

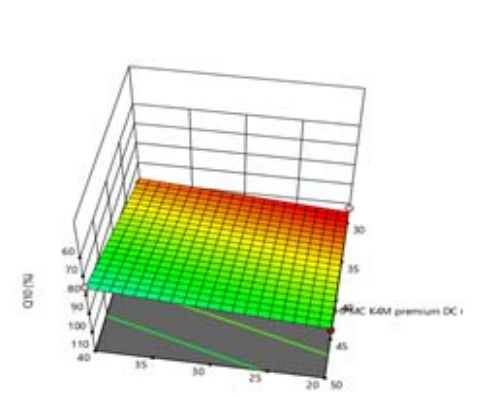

(c)

Fig. 7 Response surface plot for drug release at $10 \mathrm{~h}(\mathrm{Q} 10)(\mathrm{n}=3)$, Fig. 7 (a) Drug release at $10 \mathrm{~h}$ when concentration of SLS is 0 , Fig.7(b) Drug release at $10 \mathrm{~h}$ when concentration of SLS is 5, Fig. 7(c) Drug release at $10 \mathrm{~h}$ when concentration of SLS is 10 
The statistical data obtained from ANOVA for the models is represented in table VII. From the ANOVA analysis, it can be observed that HPMC K4M DC2 Premium(X1) polymer has effect on all responses Q2, Q6 and Q10reinforcing the fact that it is the main release retarding polymer that controls the drug release upto $12 \mathrm{~h}$. At two hours the coefficient, as observed from the equation in table 7 has a lesser value as this is the period of establishment of a fully swollen gel matrix. This is also reinforced by the swelling index of the tablet as depicted in fig. 8 for optimised batch BS09. It was also observed that as the HPMC content per tablet increases the swelling index also increases.
Pregelatinized starch has significant influence at $6 \mathrm{~h}$ as observed from the equation in table. It forms a synergistic gel matrix with HPMC. The influence of SLS as solubilser for drug is most predominant from $6 \mathrm{~h}$ onwards till $12 \mathrm{~h}$. Since $\mathrm{P}<0.05$ for all three responses, indicates that the model is significant. $\mathrm{R}^{2}$ values indicate a high level of correlation between experimental and predicted responses. The closeness of the adjusted and predicted $\mathrm{R}^{2}$ values explains the reliability of the model. The adequate precision value of greater than 4 indicates that the model is discriminating. Since coefficient of variation CV is less than 10 the model can be considered reproducible.

Table 7: ANOVA influence of formulation variables on response factors

\begin{tabular}{|c|c|c|c|c|c|c|}
\hline Regression model & $\mathbf{R}^{2}$ & $\begin{array}{l}\text { Adjusted } \\
\mathbf{R}^{2}\end{array}$ & $\begin{array}{l}\text { Predicted } \\
\mathbf{R}^{2}\end{array}$ & $\begin{array}{l}\text { Model P } \\
\text { value }\end{array}$ & $\begin{array}{l}\% \\
\mathrm{CV}\end{array}$ & $\begin{array}{l}\text { Adequate } \\
\text { precision }\end{array}$ \\
\hline $\mathrm{Q} 2=13.90-3.05 \times 1-1.31 \times 2+0.540 \times 3$ & 0.9134 & 0.8810 & 0.8384 & 0.0001 & 7.45 & 16.3950 \\
\hline $\begin{array}{l}Q 6=51.86-7.83 \times 1-5.31 \times 2+9.80 \times 3+1.71 \times 1 * X 2-2.39 \\
X 1 * X 3\end{array}$ & 0.9937 & 0.9884 & 0.9730 & $<0.0001$ & 2.50 & 50.4568 \\
\hline $\mathrm{Q} 10=80.22-8.52 \times 1-3.28 \times 2+9.23 \times 3-2.45 \times 1 * X 3$ & 0.9686 & 0.9506 & 0.9096 & $<0.0001$ & 3.17 & 25.6130 \\
\hline
\end{tabular}

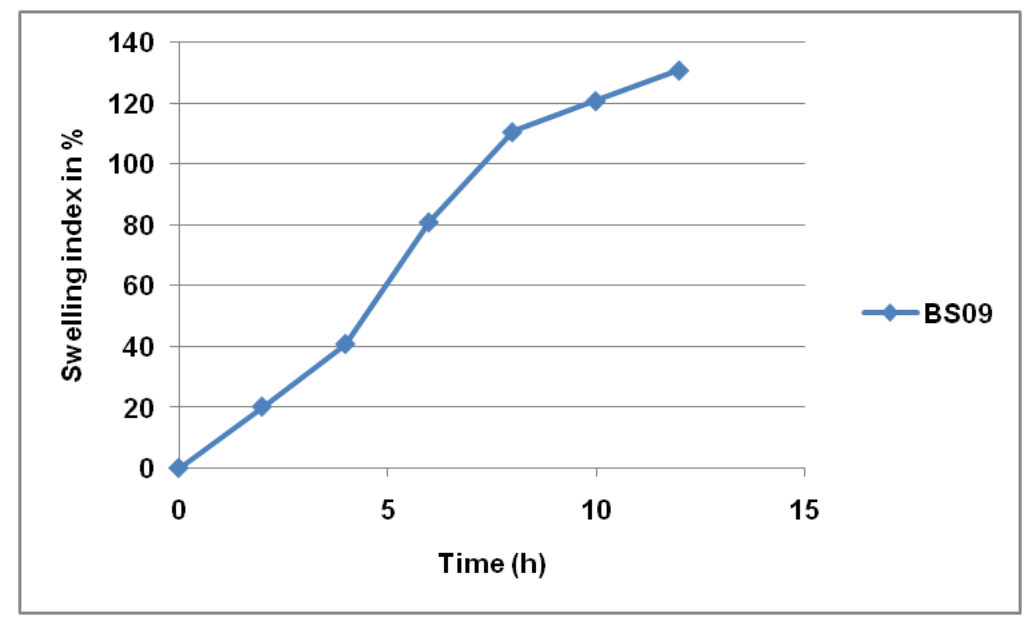

Fig. 8: Swelling index of optimised batch BS09 $($ mean \pm SD, $n=3)$

The release kinetics of all the formulations were checked by fitting the release data to various kinetic models, and the release was best fitted to zero order release mechanism. Further by fitting the data to the Korsmeyer-Peppas equation and the $\mathrm{n}$ value for all the formulations obtained was $>1$ which suggests that the release followed the super case II transport mechanism. This suggests more than one mechanism involved in drug release from matrix. The $\mathrm{r}^{2}$ values for all the models are shown in table 8 .

Stability results of the optimised batch BS09 showed optimum drug release of sildenafil citrate within $30 \mathrm{~min}$ and controlled release of bosentan over a $12 \mathrm{~h}$ period.

Table 8: Correlation coefficients of different pharmacokinetic models for release

\begin{tabular}{llllll}
\hline Formulation & zero order & first order & Higuchi & Hixon crowel & Korsmeyer-peppas $\mathbf{r}^{2} \mathbf{n}$ \\
\hline BS 01 & 0.9479 & 0.9703 & 0.949 & 0.972 & 0.8756 \\
BS 02 & 0.9872 & 0.981 & 0.9299 & 0.9889 & 0.8924 \\
BS 03 & 0.9936 & 0.969 & 0.9253 & 0.9859 & 0.8634 \\
BS 04 & 0.9963 & 0.9542 & 0.8917 & 0.9762 & 0.9289 \\
BS 05 & 0.8972 & 0.8722 & 0.9086 & 0.8444 & 0.9148 \\
BS 06 & 0.9727 & 0.9809 & 0.9408 & 0.9933 & 0.918 \\
BS 07 & 0.9669 & 0.864 & 0.9251 & 0.867 & 0.9093 \\
BS 08 & 0.9927 & 0.9556 & 0.9201 & 0.9851 & 1.76068 \\
BS 09 & 0.9947 & 0.7802 & 0.9149 & 0.9119 & 1.7243 \\
BS 10 & 0.9881 & 0.7819 & 0.9179 & 0.9005 & 1.6739 \\
BS 11 & 0.997 & 0.6618 & 0.9073 & 0.8632 & 1.6989 \\
BS 12 & 0.9925 & 0.8644 & 0.9266 & 0.9498 & 0.9129 \\
\hline
\end{tabular}

\section{CONCLUSION}

The above study demonstrates the use of a factorial design approach in an optimisation of bilayer tablet dosage form of bosentan monohydrate and sildenafil citrate in the management of pulmonary arterial hypertension. The amount of HPMC and amount of pregelatinized starch has the significant influence on in vitro drug release. SLS acts as a solubilizer exhibiting significant influence after $6 \mathrm{~h}$. The statistical tool design expert trial version 11 was used to predict the interaction between the variables and the extent of their influence on drug release. 
The direct compression technique for manufacture of this bilayer tablet is a safe and effective tool for patients failing monotherapy in pulmonary arterial hypertension. Bilayer tablets are an ideal way of administering drugs as fixed dose combinations for lifestyle diseases.

\section{ACKNOWLEDGEMENT}

My sincere gratitude to my guide Dr. H. M. Tank, for his guidance and support throughout the work. The authors are thankful to Mr. Anant Naik of Unichem Laboratories and Cipla Ltd. for providing gift sample of drugs and to Dr. S. N. Mamle Dessai, Principal of PES's Rajaram and Tarabai Bandekar College of Pharmacy for providing facility to carry out the research work.

\section{AUTHORS CONTRIBUTIONS}

Pearl Pires Dighe, corresponding author for this publication, working as Assistant Professor has carried out all the above research work in the premises of PES's Rajaram and Tarabai Bandekar College of Pharmacy under the guidance of her Ph. D guide Dr. H. M. Tank, Principal, Atmiya Institute of Pharmacy, Dist. Rajkot.

\section{CONFLICT OF INTERESTS}

All authors have none to declare

\section{REFERENCES}

1. Corris P, Degano B. Severe pulmonary arterial hypertension: treatment options and the bridge to transplantation. Eur Respir Rev 2014;23:488-97.

2. Gabbay E, Fraser J, McNeil K. Review of bosentan in the management of pulmonary arterial hypertension. Vasc Health Risk Manage 2007;3:887-900.

3. Weber C, Schmitt R, Birnboeck H, Hopfgartner G, Van Marle SP, Peeters PA, et al. Pharmacokinetics and pharmacodynamics of the endothelin-receptor antagonist bosentan in healthy human subjects. Clin Pharmacol Ther 1996;60:124-37.

4. Ghazwan B. The role of phosphodiesterase inhibitors in the management of pulmonary vascular diseases. Glob Cardiol Sci Pract 2014;3:257-90.

5. Klodell CT Jr, Morey TE, Lobato EB, Aranda JM Jr, Staples ED, Schofield RS, et al. Effect of sildenafil on pulmonary artery pressure, systemic pressure, and nitric oxide utilization in patients with left ventricular assist devices. Ann Thorac Surg 2007;83:68-71.

6. Dardi F, Manes A, Palazzini M, Bachetti C, Mazzanti G, Rinaldi A et al. Combining bosentan and sildenafil in pulmonary arterial hypertension patients failing monotherapy: real-world insights. Eur Respir J 2015;46:414-21.

7. Vishwakarma AG, Mogal RT, Pawar AY. Bi-Layer tablet-a new ways in oral drug delivery system. Int J Pharm Tech Res 2014;6:1416-28.

8. Arunprashad B, Teja GK. Design and evaluation of bilayer tablets to treat respiratory tract infection. Int J Pharm Pharm Sci 2013;5:250-5.

9. Roy S, Naskar S, Kundu S, Kpoutsu K. Formulation and evaluation of sustained release bilayer tablets of propranolol hydrochloride. Int J Pharm Pharm Sci 2015;7:264-9.

10. Kumar U, Md SamiulI, Halder S, Rouf A. Assessment of once daily sustained release hydrophilic matrix tablet of carvedilol. Dhaka Univ J Pharm Sci 2017;16:43-53.

11. Brito SR, Sravani G, Bhanupriya N, Veerupakshi M, Anil Kumar $B$, Wasim Raja S. Design and evaluation of sustained release bilayer tablet of metformin hydrochloride with metoprolol tartrate. Int J Novel Trends Pharm Sci 2011;1:10-7.

12. Prabhakar S. Formulation and evaluation of bilayer tablets of diclofenac sodium with ranitidine HCL for sustained and immediate release. J Appl Pharma Sci 2012;2:136-41.

13. Jivani RR, Patel CN, Jivani NP. Statistical design of experiments on the fabrication of bilayer tablet of narrow absorption window drug: development and in vitro characterisation. Indian J Pharm Sci 2012;74:302-11.

14. Bobde SS, Tank HM. Design and statistical optimization of mouth dissolving sublingual film of fixed dose combination of doxylamine succinate and pyridoxine hydrochloride using the design of experiment in the treatment if nausea and vomiting. Asian J Pharm Clin Res 2018;11:202-8.

15. Chime SA, Onunkwo GC, Onyishi II. Kinetics and mechanisms of drug release from swellable and non swellable matrices: a review. Res J Pharm Biol Chem Sci 2013;4:97-103.

16. International Conference of Harmonization (ICH). Harmonized Tripartide Guidelines for Stability Testing of New Drug Substances and Products Q1A (R2). Rockville, MD: United States Pharmacopoeial Convention, Inc.; 2003. p. 6. 